\title{
Operational Study of Drone Spraying Application for the Disinfection of Surfaces against the COVID-19 Pandemic
}

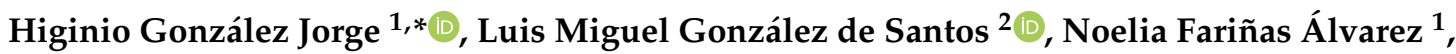 \\ Joaquin Martínez Sánchez ${ }^{2}$ and Fermin Navarro Medina ${ }^{3}$ \\ 1 Department of Natural Resources and Environmental Engineering, School of Aerospace Engineering, \\ University of Vigo, 32004 Ourense, Spain; noelia.farinas.alvarez@uvigo.es \\ 2 CINTECX, GeoTECH Group, Campus Universitario de Vigo, University of Vigo, As Lagoas, Marcosende, \\ 36310 Vigo, Spain; luismgonzalez@uvigo.es (L.M.G.d.S.); joaquin.martinez@uvigo.es (J.M.S.) \\ 3 Department of Mechanical Engineering, Thermal Machines and Motors, and Fluids, School of Aerospace \\ Engineering, University of Vigo, 32004 Ourense, Spain; fermin.navarro.medina@uvigo.es \\ * Correspondence: higiniog@uvigo.es
}

\section{check for}

updates

Citation: González-Jorge, H.; González-deSantos, L.M.;

Fariñas-Álvarez, N.;

Martínez-Sánchez, J.;

Navarro-Medina, F. Operational Study of Drone Spraying Application for the Disinfection of Surfaces against the COVID-19 Pandemic. Drones 2021, 5, 18. https://doi.org/ $10.3390 /$ drones5010018

Academic Editor: Paul Royall

Received: 29 January 2021

Accepted: 4 March 2021

Published: 7 March 2021

Publisher's Note: MDPI stays neutral with regard to jurisdictional claims in published maps and institutional affiliations.

Copyright: (c) 2021 by the authors. Licensee MDPI, Basel, Switzerland. This article is an open access article distributed under the terms and conditions of the Creative Commons Attribution (CC BY) license (https:// creativecommons.org/licenses/by/ $4.0 /)$.

\begin{abstract}
The COVID-19 pandemic has shown the need to maximize the cleanliness of outside public services and the need to disinfect these areas to reduce the virus transmission. This work evaluates the possibilities of using unmanned aircraft systems for disinfection tasks in these aeras. The operational study focuses on evaluating the static and dynamic behavior, as well as the influence of the flying height, mission speed and flow of spraying. The most recommended height for correct spraying with the drone system under study is $3.0 \mathrm{~m}$. The dynamic test shows that the lower height, $3.0 \mathrm{~m}$, also provides the most adequate spraying footprint, achieving $2.2 \mathrm{~m}$ for a speed of $0.5 \mathrm{~m} / \mathrm{s}$. The operational behavior is evaluated on three different scenarios, a skatepark with an area around $882.7 \mathrm{~m}^{2}$, an outdoor gym with an area around $545.0 \mathrm{~m}^{2}$ and a multisport court with an area around $2025.7 \mathrm{~m}^{2}$. The cleaning time evaluates the flying duration, battery change and tank refill and results in $41 \mathrm{~min}$ for the skatepark ( 5 tank refills and 2 battery changes), $28.6 \mathrm{~min}$ for the outdoor gym ( 3 tank refills and 2 battery changes) and $96.4 \mathrm{~min}$ for the multisport court (11 tank refills and 5 battery changes). Each battery change and each tank refill are estimated to take $4 \mathrm{~min}$ each, with a drone autonomy of $7 \mathrm{~min}$. The technology appears competitive compared to other forms of cleaning based, for example, on human operators.
\end{abstract}

Keywords: drone spraying; COVID-19; drone cleaning; aerial works

\section{Introduction}

Unmanned aircraft systems (UAS), also called drones, are a technology that has extended its use in recent years to many applications such as the audiovisual sector, surveying, infrastructure inspection, agriculture, forestry management and logistics, among others [1-6]. This technology shows advantages such as avoiding the use of helicopters in many aerial works, greatly decreasing the cost of operation. Imagery from UAS also increases the spatial resolution in comparison with other solutions based on satellites, due to the greater proximity between the optical sensor and the scanned surface. In addition, they give safe accessibility to complicated parts of large structures and avoid the use of human workers at height with the need for harnesses, cranes or winches.

One of the operational segments of activity where UAS are expected to continue growing in the incoming years is drone spraying. Some countries such as South Korea spray about the $30 \%$ of their agricultural area with drones. Unmanned helicopters, such as the Yamaha RMax [7], pioneered drone spraying in Japan, dating back the mid-1990s, whilst others were recently introduced in the market, such as DJI Agras MG-1 [8] in 2016. Legal and technical barriers must be addressed to increase the scope of drone spraying. Legislation needs to be updated to accommodate the use of pesticides in some countries [9]. 
Among technical parameters, altitude control is a critical aspect to be considered in drone spraying to achieve a balanced fluid application to the entire agricultural parcel [10].

Even though drone spraying has been oriented mainly to agricultural work, the current coronavirus pandemic has shown other applications related to cleaning public spaces with drones. In those cases, water is mixed with a disinfectant fluid that is dispersed on a surface. Although there are various press reports regarding its application [11-13], no serious scientific studies are presented on its real viability.

The aim of the present work is to study the potential use of drones in surface cleaning, considering different technical parameters. Virucidal dilutions can be prepared following the recommendations of the Spanish Health Service [14]. Aspects such as the adequate flying height, mission speed, spraying flow or time requirements are analyzed in the manuscript. The manuscript is focused on the liquid coverage in the field, not on the effectiveness of the disinfectant process. The manuscript is organized as follows: Section 2 shows the Material and Methods part, where drone characteristics are presented, as well as the study area and spraying testing methodology. Section 3 depicts the results and discussion. Section 4 exhibits the conclusions.

\section{Materials and Methods}

\subsection{Spraying Drone}

The used spraying drone was the MX405 (Figure 1) [15]. It uses a flight control system, K3A Pro, with four 24" propellers and 6125/340kv brushless motors. The frame is made of carbon fiber. Whilst the folding size is $472 \times 472 \times 444 \mathrm{~mm}$, the distance between propeller axes is $1000 \mathrm{~mm}$ when unfolded, producing a product size of $776 \times 776 \times 444 \mathrm{~mm}$. The tank capacity is $5.5 \mathrm{~L}$ with a maximum takeoff weight of $14 \mathrm{~kg}$. The working time is $7 \mathrm{~min}$ with a maximum working area of $20.000 \mathrm{~m}^{2}$ (2 Ha). Fluid spaying was conducted using a brushless pump with a pressure nozzle. It uses a 6S 22,000 mAh LiPo battery as the energy source. The maximum tilt is $30^{\circ}$, maximum yaw speed is $150^{\circ} / \mathrm{s}$ and maximum vertical speed is $6 \mathrm{~m} / \mathrm{s}$.

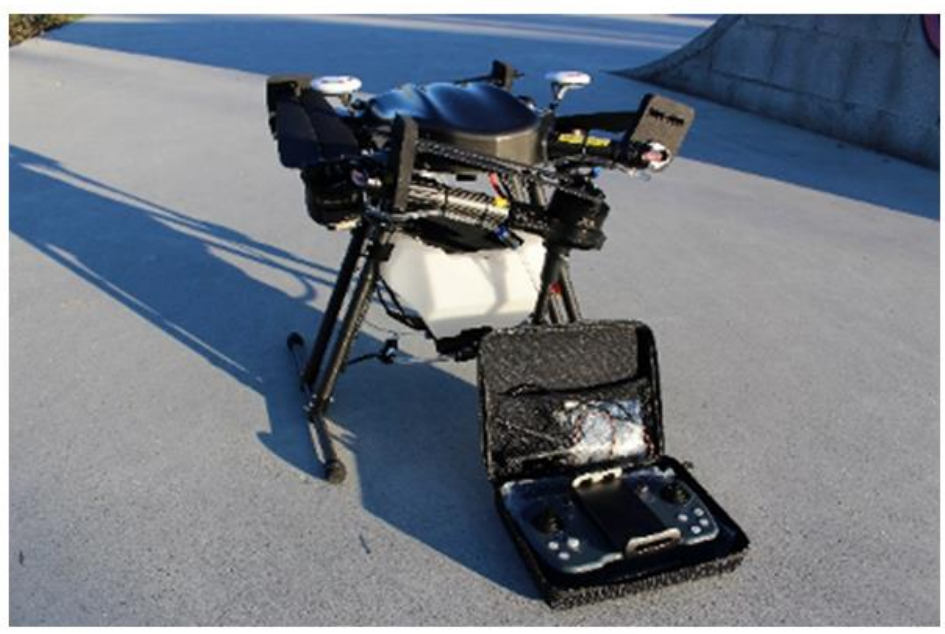

(A)
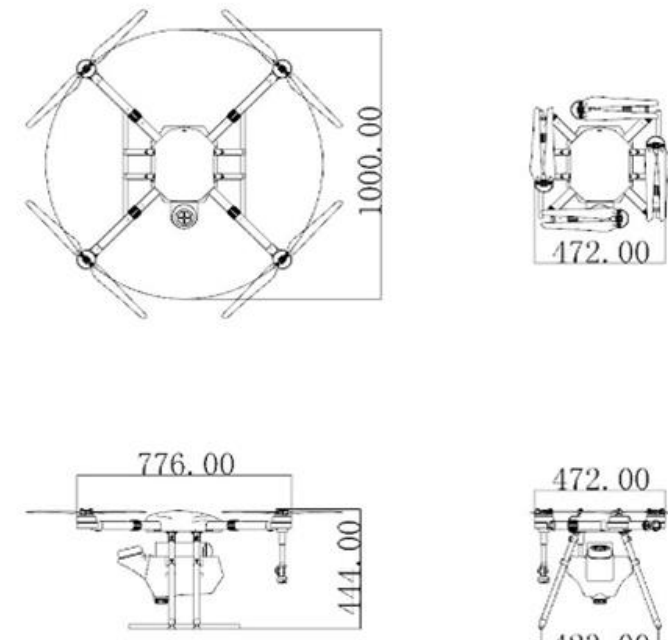

472. 00

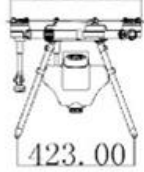

(B)

Figure 1. MX405 drone. Image (A) and drawing (B). Length in $\mathrm{mm}$.

\subsection{Testing Sites and Weather}

Testing sites were defined in order to perform outdoor operations with global navigation satellite system (GNSS) coverage. This fact facilitates the navigation of the drone and the path planning. If possible, GNSS RTK (global navigation satellite system-real time kinematics) is preferred to ensure accurate navigation and guarantee no areas without 
cleaning treatment. In addition, a RADAR system is also important to provide flying stability and keep a constant drone-ground distance. Local drone rules should be taken into account (i.e., pilot license, operator license, maximum takeoff weight of the drone, flight height). In addition, the regulations in Europe forbid the presence of people under the drone flying area during operations. This is the general scenery applicable to this work.

Three testing sites with potential interest for the disinfection of surfaces with drones in the Galicia region (northwest Spain) were selected: a skatepark and an outdoor gym in the municipality of Nigrán, and a multisport court in the municipality of Mondariz (Figure 2). The skatepark had an area around $882.7 \mathrm{~m}^{2}$, the outdoor gym had an area of $525.0 \mathrm{~m}^{2}$ and the multisport court had an area of $2036.7 \mathrm{~m}^{2}$. To obtain the geometrical information and an aerial image of the areas under study, photogrammetric flights using the DJI Mavic Mini drone [16] were performed. The flights were conducted with $80 \%$ overlap in the along-track direction and $50 \%$ in the cross-track direction. The DJI Mavic Mini drone only weight $249 \mathrm{~g}$ and it is highly portable. It has a $12 \mathrm{MP}$ digital camera with a field of view of $83^{\circ}$ and a $35 \mathrm{~mm}$ equivalent, $24 \mathrm{~mm}$ lens ( $\mathrm{f} / 2.8$ ). Photogrammetric reconstructions were conducted using the Agisoft Metashape software suite [17]. Control points to provide real dimensions were marked using the Leica GS15 GNSS in RTK mode with accuracies of 5 (horizontal) and $10 \mathrm{~mm}$ (vertical) [18]. The first testing site (skatepark; Nigrán municipality) was used for the study and calibration of the drone spraying features. The two additional sites were used for an operational study of the technology, based on the previous evaluated drone spraying features.

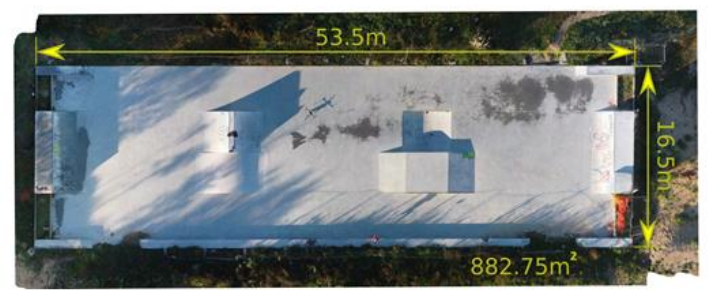

(A)

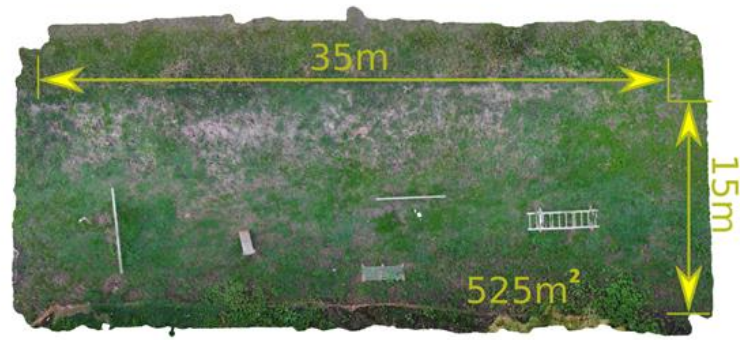

(B)

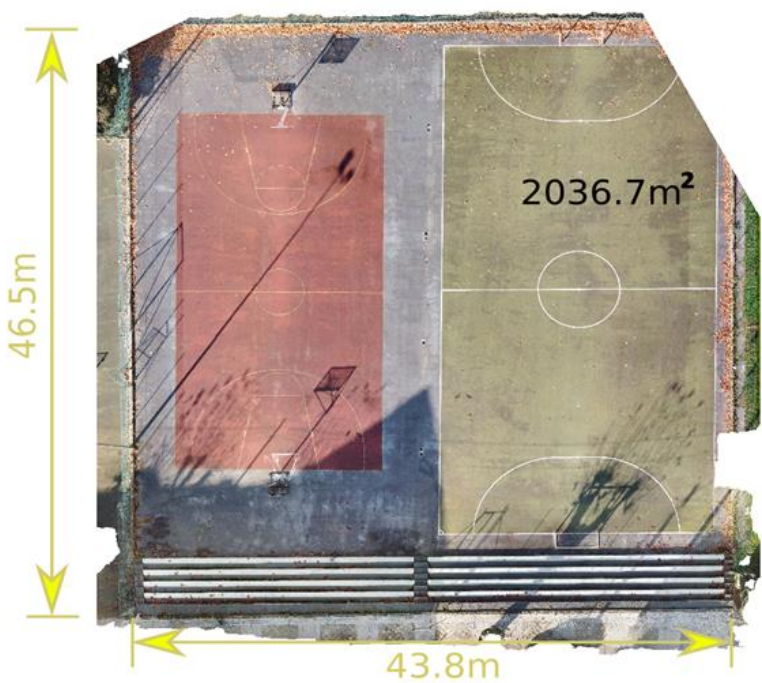

(C)

Figure 2. Testing site orthoimages: (A) skatepark (Nigrán municipality); (B) outdoor gym (Nigrán municipality); (C) multisport court (Mondariz municipality).

Wind speed data during the drone spraying testing at the skatepark in Nigrán municipality were obtained from the weather stations of Meteogalicia, situated in the surrounding area [19]. This service has a dense network of weather stations in the Galician territory and provides accurate information of wind speed at $10 \mathrm{~m}$ height, which is applicable to this study. Wind speed for the testing day (Nov 21 2020) was $2.2 \mathrm{~km} / \mathrm{h}$. Due to the small size of the dispersed droplets, low wind speed is crucial during drone operation. This ensures that the applied liquid reaches the ground below the drone and does not disperse in the air. Other meteorological aspects, such as the absence of rain to guarantee the application of the product in the appropriate concentration, or the absence of fog to guarantee visibility, must be taken into account. 


\subsection{Testing Methodology}

The testing methodology started with the evaluation of the spraying flow. The spraying flow of the system could be set up in the mobile app provided by the manufacturer. To verify this flow, a test was carried out which consisted of introducing a known volume of liquid in the drone container and measuring the time it takes the system to disperse all the fluid. The test was conducted by introducing $2 \mathrm{~L}$ into the tank. The spraying time up to emptying the tank was $70 \mathrm{~s}$. The spraying flow calculated was $1.7 \mathrm{~L} / \mathrm{min}$.

After this calculation, the static and dynamic footprints of the drone spraying were evaluated. In both cases, a plastic container of known dimensions was used to take fluid from the ground (Figure 3). The system shows a surface of $753.7 \mathrm{~cm}^{2}$.

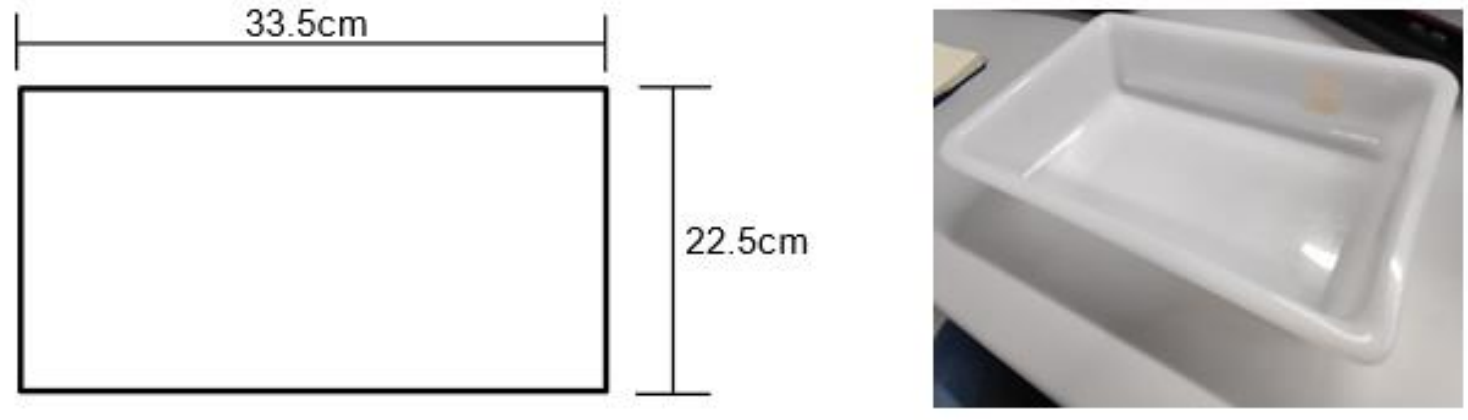

Figure 3. Plastic container to collect liquid during testing.

The static footprint defines the surface affected by the fluid during a hover spraying at different heights. Time during spraying was $30 \mathrm{~s}$ and heights involved were 3.0, 5.0 and $7.0 \mathrm{~m}$. Two containers were placed on the ground on the spraying surface, one in the same $\mathrm{X}-\mathrm{Y}$ coordinates of the drone hovering and the other one at $1.0 \mathrm{~m}$ distance.

The dynamic footprint defines the behavior of drone spraying at a pre-defined mission speed. In this case, the test consisted of moving the drone linearly at a speed of $0.5 \mathrm{~m} / \mathrm{s}$ and defining the ground footprint. The same containers used in previous tests were also used to measure the fluid recovered from the ground. Flying heights over the ground were also 3.0, 5.0 and $7.0 \mathrm{~m}$.

\section{Results and Discussion}

Figure 4 shows an example of the static footprint at 3.0, 5.0 and $7.0 \mathrm{~m}$ on the skate park of Nigrán municipality. Table 1 shows the fluid volume recovered in each container at different flight heights during the static footprint test. As it was expected, the footprint dimensions increase with height, but the container's volume of fluid decreases. In addition, although the wind speed was slow during the tests $(2.2 \mathrm{~km} / \mathrm{h})$, it decreased the accuracy of the footprint with the height increase.

Table 1. Static footprint test results. Spraying time: $70 \mathrm{~s}$.

\begin{tabular}{cccc}
\hline Flight Height $(\mathbf{m})$ & $\begin{array}{c}\text { Footprint } \\
\text { Dimensions }(\mathbf{m})\end{array}$ & $\begin{array}{c}\text { Container 1 Volume } \\
(\mathbf{m L})\end{array}$ & $\begin{array}{c}\text { Container 2 Volume } \\
(\mathbf{m L})\end{array}$ \\
\hline 3 & $2.9 \times 2.5$ & 33 & 8 \\
5 & $4.0 \times 3.5$ & 3 & 12 \\
7 & $5.1 \times 4.1$ & 1 & 3 \\
\hline
\end{tabular}



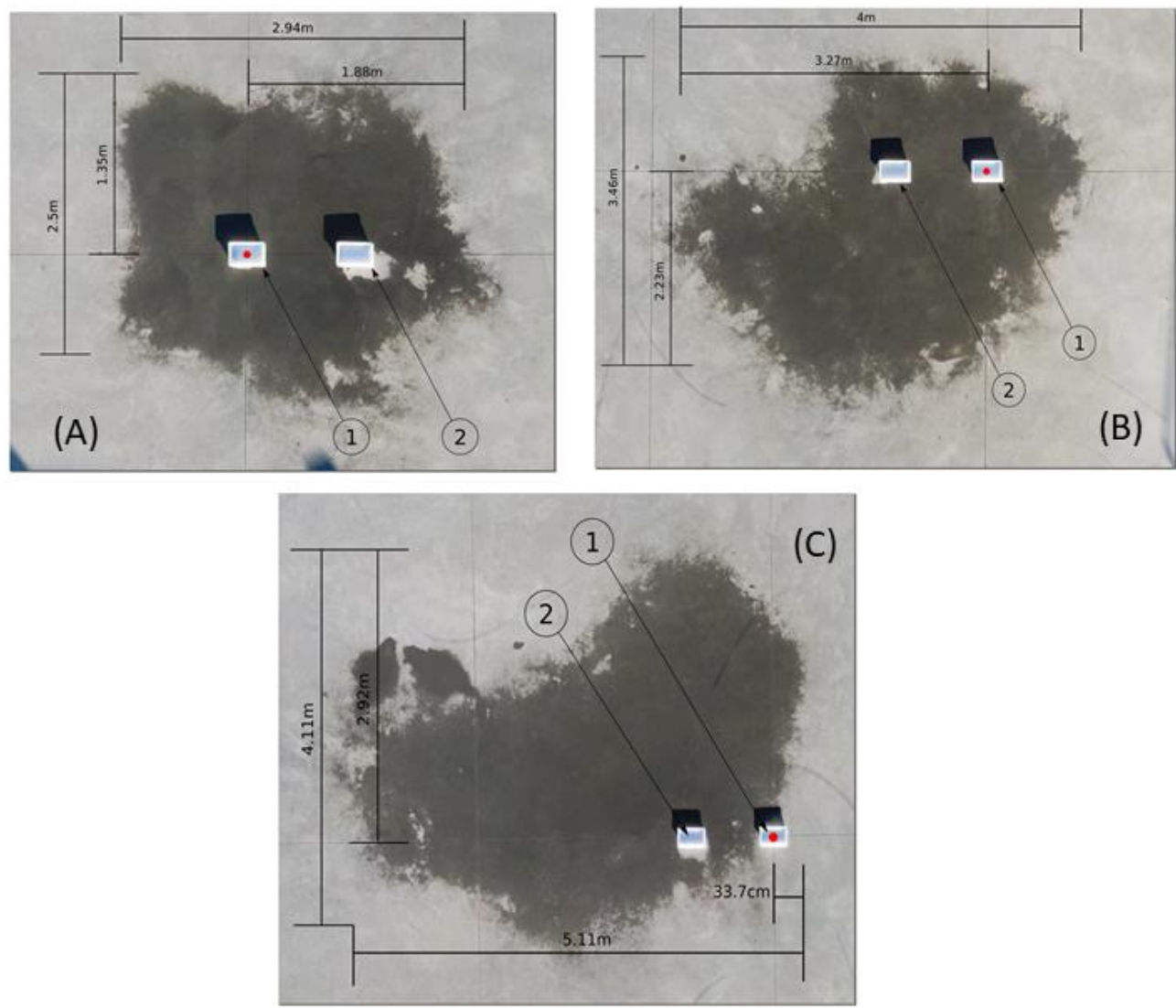

Figure 4. Example of static footprint (darker gray area) on the skatepark in Nigrán municipality. (A) $3.0 \mathrm{~m}$ height, (B) $5.0 \mathrm{~m}$ height, (C) $7.0 \mathrm{~m}$ height. Red point on container 1 indicates the X-Y position of the drone.

Figure 5 depicts an example of the dynamic footprint at 3.0, 5.0 and $7.0 \mathrm{~m}$ on the same previous place. Table 2 shows the width of the footprint during the dynamic test and the volume of fluid recovered from the containers. The footprint loses uniformity with the increasing height. At a height of $7.0 \mathrm{~m}$, no fluid is recovered from the container and the footprint is narrow, making any form of cleaning with the system difficult.

Table 2. Dynamic footprint results.

\begin{tabular}{cccc}
\hline Flight Height $(\mathbf{m})$ & Footprint Width $(\mathbf{m})$ & $\begin{array}{c}\text { Container 1 Volume } \\
(\mathbf{m L})\end{array}$ & $\begin{array}{c}\text { Container 2 Volume } \\
(\mathbf{m L})\end{array}$ \\
\hline 3 & 2.4 & 2 & - \\
5 & 2.1 & 1 & - \\
7 & - & - & - \\
\hline
\end{tabular}

As shown in the tests carried out with the system, the dispersion is greatly affected by the wind, both in the footprint position and width. In view of these results, the optimal height to ensure that the dispersed liquid covers the entire desired surface uniformly is $3 \mathrm{~m}$. Furthermore, with the tank capacity of $5.5 \mathrm{~L}$ and the dispersion flow of the system, which is $1.7 \mathrm{~L} / \mathrm{min}$, the drone could fly at $96.1 \mathrm{~m}$, dispersing liquid at a speed of $0.5 \mathrm{~m} / \mathrm{s}$. Flying at a height of $3.0 \mathrm{~m}$ and considering the width of the footprint obtained in the dynamic test, it can be concluded that the system covers an area of $228.8 \mathrm{~m}^{2}$ with the $5.5 \mathrm{~L}$ tank.

Considering the previous study, assumed as the calibration of the technology, an operational study was performed for all the testing sites under study (Table 3). A flight height of $3 \mathrm{~m}$ over the places was selected, with a $2.2 \mathrm{~m}$ footprint to guarantee maximum coverage and overlap between the different strips. The other operational parameters such as 
speed and spraying flow were the same as those previously tested $(0.5 \mathrm{~m} / \mathrm{s}$ and $1.7 \mathrm{~L} / \mathrm{min}$, respectively). Figure 6 shows an example of the cleaning mission simulated that requires seven strips to clean all of the surface. Table 3 shows the results for all the sites under study. Total flight distance was calculated as the sum of strips' length plus the width of the rectangle. The required number of tanks to perform all the spraying task was estimated taking into account the length of $96.1 \mathrm{~m}$, the drone speed of $0.5 \mathrm{~m} / \mathrm{s}$ and the spraying flow of $1.7 \mathrm{~L} / \mathrm{min}$. Flying time is calculated from the speed of the mission and the total length for spraying. Considering the autonomy of the system $(7 \mathrm{~min})$, the number of battery changes to perform the complete mission is automatically obtained. Battery replacement operation is estimated based on authors' previous experience of needing $4 \mathrm{~min}$, and the tank refill adds another $4 \mathrm{~min}$ to the operation. These data added to the flight time provide the total time for the cleaning mission. The correlation between the cleaning area and time is evaluated and represented by the following equation: Total time $(\mathrm{min})=0.0456 \cdot$ Area $\left(\mathrm{m}^{2}\right)+2.95$.
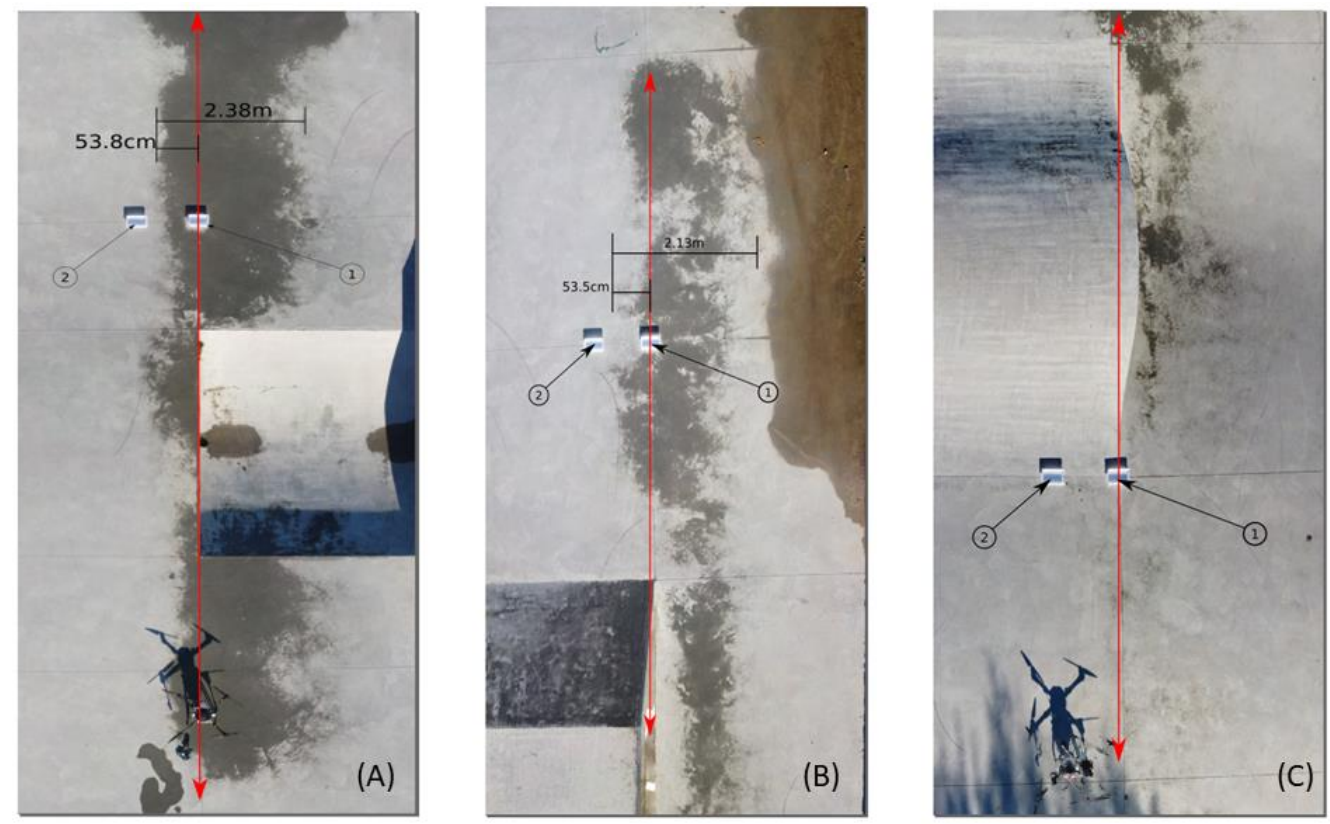

Figure 5. Example of dynamic footprint (darker gray area) on the skatepark in Nigrán municipality. (A) $3.0 \mathrm{~m}$ height, (B) $5.0 \mathrm{~m}$ height, (C) $7.0 \mathrm{~m}$ height. Red arrow indicates the X-Y position of the drone path.

Table 3. Results of operational study for spray cleaning using a drone.

\begin{tabular}{cccc}
\hline Parameters & Skate Park & Outdoor Gym & Multisport Court \\
\hline Area $\left(\mathrm{m}^{2}\right)$ & 882.7 & 525.0 & 2036.7 \\
Length $(\mathrm{m})$ & 53.5 & 35.0 & 46.5 \\
Width $(\mathrm{m})$ & 16.5 & 15.0 & 43.8 \\
Strips & 7 & 7 & 20 \\
Total flight distance (m): length & 391.0 & 260.0 & 973.8 \\
strips + width & 5 & 3 & 11 \\
Number of tank refills & 22.3 & 14.8 & 55.7 \\
Disinfectant volume (L) & 13.0 & 8.6 & 32.4 \\
Flying time (min) & 2 & 2 & 5 \\
Battery changes (autonomy 7 min) & & & \\
Total time (min): Flying time + & 41.0 & 28.6 & 96.4 \\
battery changes time + tank & & & \\
refill time & & &
\end{tabular}




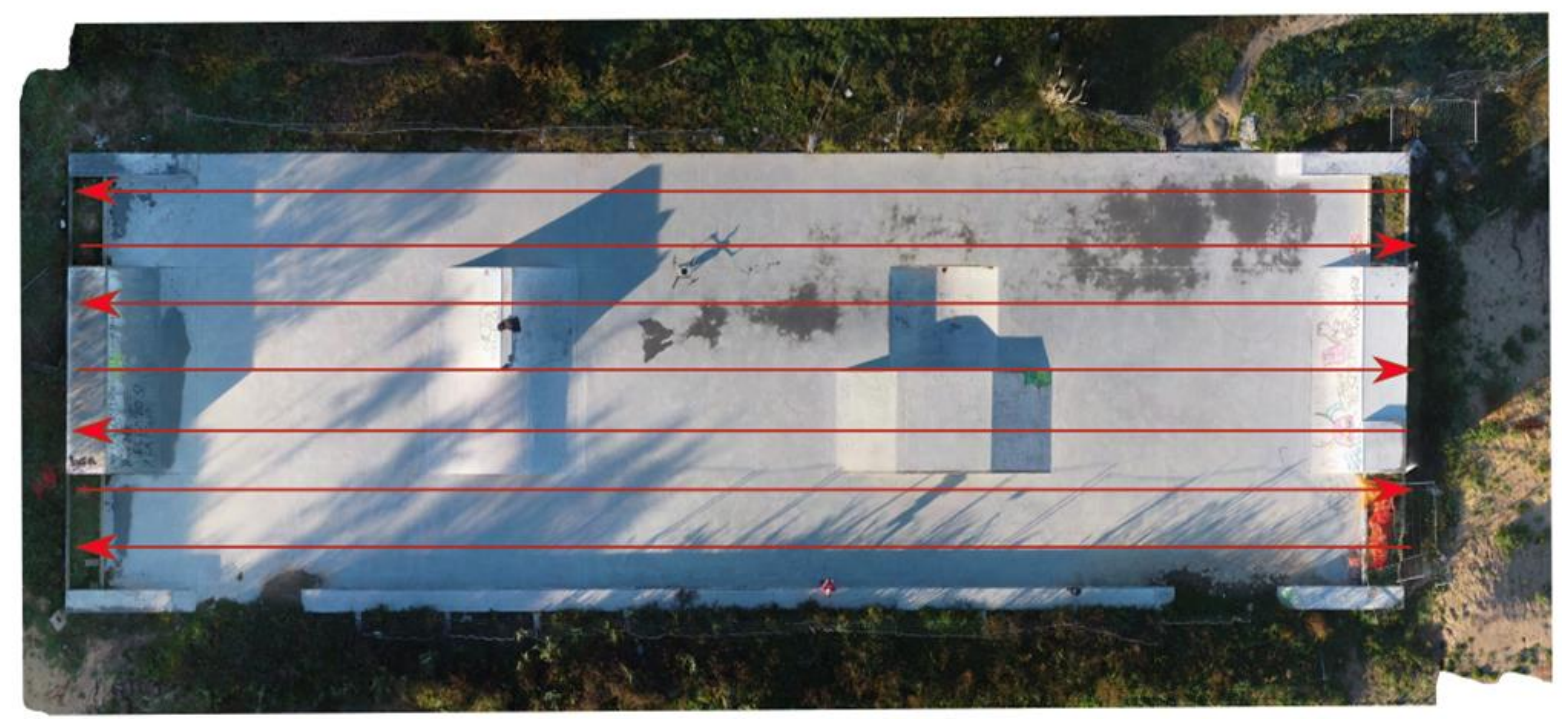

Figure 6. Example of mission planning for drone spraying cleaning at the skatepark in Nigrán municipality. Red arrows indicate drone strips.

\section{Conclusions}

A spraying drone system was tested for disinfection purposes in open scenarios usually shared by people as an outdoor gym, a multisport court with stands and a skatepark. The disinfection of these locations is challenging with other methodologies (humans with spraying backpack or spraying trucks), especially in some areas such as the stands of the multisport court or some elements of the outdoor gym. Man-made works are slow and cannot carry large volumes of fluid. Due to their nature, they also do not guarantee that the work is performed as a systematic procedure. On the other hand, the use of trucks generates an accessibility problem since they cannot reach many spaces.

The experiments performed show how the use of drones appears as reliable and efficient. They provide an accurate spraying that could be parameterized and cost evaluated. Static and dynamic tests were performed. Static tests show a great influence in the footprint quality with the wind, even for lower wind speeds. This influence increases with the increasing flight height. The most recommended height for correct spraying with the drone system under study is $3 \mathrm{~m}$. Dynamic tests show that the lower height also provides the most adequate spraying footprint, achieving $2.4 \mathrm{~m}$ for a speed of $0.5 \mathrm{~m} / \mathrm{s}$.

The characteristics of the operation were evaluated in the three different scenarios. It can be concluded that the cleaning of the skatepark needs $41.0 \mathrm{~min}$, the outdoor gym needs $28.6 \mathrm{~min}$ and the multisport court needs $96.4 \mathrm{~min}$. In addition, it must be noted that the operation could be performed using only one drone pilot, which makes it cost-competitive against other cleaning methodologies.

For future work, it would be of interest to study other drones in the market that can load larger volumes of liquid, such as the DJI Agras or the YamahaR-Max. They would surely increase the productivity of the method, since one of the greater delays in the procedure is related to the deposit recharge time. The development of an automatic ground refill station could also contribute to improving this limitation, maybe in combination with drone battery recharging stations. On the other hand, there are open issues that require more research in future. At the biochemical level, the appropriate drop size for disinfection with this type of system, the optimal thickness of the water sheet that is generated on the ground or what type of cleaning solution is most recommended should be determined. There are other open issues related to the lack of GNSS signal and the operation in indoor environments, as well as the management of unforeseen obstacles such as railing and cables. 
Author Contributions: Conceptualization, H.G.-J., J.M.-S., F.N.-M.; methodology, H.G.-J., L.M.G.-S., N.F-A.; testing, L.M.G.-S., N.F.-A.; results analysis, H.G.-J., J.M.-S., F.N.-M.; writing and editing, H.G.-J., J.M.-S. All authors have read and agreed to the published version of the manuscript.

Funding: This research was funded by the Galician Innovation Agency (GAIN) from the regional government of Xunta de Galicia, Spain.

Acknowledgments: Authors thank Miguel Angel González-deSantos for all support given during the flight operations.

Conflicts of Interest: The authors declare no conflict of interest.

\section{References}

1. Saari, H.; Akujarvi, A.; Holmlund, C.; Ojanen, H.; Kaivosoja, J.; Nissinen, A.; Niemeläinen, O. Visible, very near IR and short wave IT hyperspectral drone imaging system for agriculture and natural water applications. ISPRS Int. Arch. Photogramm. Remote Sens. Spat. Inf. Sci. 2017, 165-170. [CrossRef]

2. González-Jorge, H.; Martínez-Sánchez, J.; Bueno, M.; Arias, P. Unmanned aerial systems for civil applications: A review. Drones 2017, 1, 2. [CrossRef]

3. Beck, S.; Bui, T.T.; Davies, A.; Courtney, P.; Brown, A.; Geudens, J.; Royall, P.G. An evaluation of drone delivery adrenaline auto-injectors for anaphylaxis: Pharmacists' perceptions, acceptance and concerns. Drones 2020, 4, 66. [CrossRef]

4. Duarte, A.; Acevedo-Muñoz, L.; Goncalves, C.I.; Mota, L.; Sarmento, A.; Silva, M.; Fabres, S.; Borralho, N.; Valente, C. Detection of longhorned borer attack and assessment in eucalyptus plantations using UAV imagery. Remote Sens. 2020, 12, 3153. [CrossRef]

5. González-Jorge, H.; Puente, I.; Roca, D.; Martínez-Sánchez, J.; Conde, P.; Arias, P. UAV photogrammetry application to the monitoring of rubble mound breakwaters. J. Perform. Constr. Facil. 2016, 30, 04014194. [CrossRef]

6. Outay, F.; Mengash, H.A.; Adnan, M. Application of unmanned aerial vehicle (UAV) in road safety, traffic and highway infrastructure management: Recent advances and challenges. Transp. Res. Part A Policy Pract. 2020, 141, 116-129. [CrossRef] [PubMed]

7. Yamaha R-Max Helicopter. Available online: https:/ / www.yamahamotorsports.com/motorsports/pages / precision-agriculturermax (accessed on 15 December 2020).

8. DJI Agras MD1 UAV. Available online: https://www.dji.com/es/mg-1 (accessed on 15 December 2020).

9. Petty, R.V. Drone Use in Aerial Pesticide Applications Faces Outdated Regulatory Hurdles. Harv. J. Law Technol. Dig. 2018, 1-14. Available online: https:/ /jolt.law.harvard.edu/assets/digestImages/Digest_Petty_Ryan_Note_Fall17_Final.pdf (accessed on 15 December 2020).

10. Hentschke, M.; de Freitas, E.P.; Henning, C.H.; da Veiga, I.C.G. Evaluation of altitude sensors for a crop spraying drone. Drones 2018, 2, 25. [CrossRef]

11. China's Drone Army Fighting Coronavirus: Farm, Police and Personal Drones Are Repurposed to Spray Disinfectant over Villages and Cities Hit by Killer Virus. Available online: https://www.dailymail.co.uk/news/article-7952119/Drones-repurposed-spraydisinfectant-villages-cities-China-hit-coronavirus.html (accessed on 15 December 2020).

12. Coronavirus: Should the UK Use Drones to Disinfect Public Spaces? Available online: https://www.bbc.co.uk/news/health-52 109824 (accessed on 16 December 2020).

13. Spain's Military Uses DJI Agricultural Drones to Spray Disinfectant in Fight against Covid-19. Available online: https://www. scmp.com/tech/gear/article/3077945/spains-military-uses-dji-agricultural-drones-spray-disinfectant-fight (accessed on 16 December 2020).

14. Spanish Health Service. Available online: https://www.mscbs.gob.es/profesionales/saludPublica/ccayes/alertasActual/nCov/ documentos/Listado_virucidas.pdf (accessed on 25 January 2021).

15. Sprayer Drone MX405. Available online: https://twenkleelectrics.com/product/mx405-portable-ulv-electric-sprayer-sprayeratomizer-garden-motor-operated-pesticide-agricultural-sprayer-drones-mx405-white/ (accessed on 16 December 2020).

16. DJI Mavic Mini UAV. Available online: https://www.dji.com/es/mavic-mini (accessed on 17 December 2020).

17. Agisoft Software. Available online: https://www.agisoft.com/ (accessed on 17 December 2020).

18. Leica GPS GS15. Available online: https://cpe.leica-geosystems.com/es/rover-gs15.html (accessed on 17 December 2020).

19. Meteogalicia Weather Stations. Available online: https://www.meteogalicia.gal/observacion/rede/redeIndex.action (accessed on 17 December 2020). 